\title{
PROSUĐiVANJE POLITIČARA NA MORALNOJ OSNOVI
}

\author{
Neven Petrović \\ Filozofski fakultet u Rijeci
}

„Tko je to savršeno čist pa mirne duše sudi o drugima?”, Novak, K. Ciganin, ali najljepši, str. 341

\section{SAŽETAK}

Tekst preispituje rasprostranjenost prakse da se političarima ili kandidatima za političku funkciju nalaze moralni nedostaci, te ih se zbog njih pokušava smijeniti ili im se ne dozvoljava da do funkcije uopće dođu. Glavna je autorova teza da je takva praksa u mnogim slučajevima iracionalna jer onemogućuje da na pozicije od javnog interesa dođu sposobni ljudi. Kako bi se ova tvrdnja obranila, spomenuti se moralni propusti najprije klasificiraju a potom se nude tri glavna argumenta kojima se želi pokazati da u barem tri vrste slučajeva političari svoj nemoral ne bi trebali plaćati funkcijom na kojoj se nalaze ili na koju aspiriraju. Na kraju se razmatraju i neki mogući prigovori iznesenom stajalištu.

KLJUČNE RIJEČI: čisto privatni nemoral, konsekvencijalizam, moralizam, političari, politički realizam, privatni nemoral na javnoj poziciji, prljave ruke

1.

Ono što me u ovom tekstu zanima jest naširoko uvriježena praksa da se one koji obnašaju političke funkcije i pretendente na njih javno ${ }^{1}$ prosuđuje kao podobne ili nepodobne za ta mjesta prvenstveno, ili čak isklju-

\section{Kontakt autora:}

Neven Petrović; Odsjek za filozofiju, Filozofski fakultet u Rijeci, Sveučilišna avenija 4, 51000 Rijeka. npetrovic@ffri.hr 1 Naime, tako to sigurno ne čine oni koji ih predlažu i postavljaju jer teško je vjerovati da su im takve informacije o tim pojedincima skroz nepoznate. 
čivo, na moralnoj osnovi, odnosno prema tome jesu li moralno besprijekorne, ili barem u poprilično velikoj mjeri moralno čiste, osobe ili to nisu. U praksi se učestalo dešava da mnogim od tih pojedinaca mediji i politički suparnici veoma brzo nalaze ovaj ili onaj moralni nedostatak, na ovom ili onom području života. Tako nerijetko doznajemo da su takvi ljudi, recimo, bespravno sagradili nekretninu, skrivali opseg svoje privatne imovine, prijavili prebivalište na adresi na kojoj ne žive i tako stekli određene financijske olakšice, izbjegavali plaćanje poreza, prepisali diplomski/magistarski rad ili akademski članak ili neki njihov dio, tukli suprugu ili djecu, skrivili lakši ili teži prometni prekršaj (npr. godinama vozili bez valjane vozačke dozvole, upravljali autom pijani i pokušali podmititi policajca da ih pusti, obijesnom vožnjom izazvali nesreću sa smrtnim ishodom), varali suprugu s tajnicom ili prostitutkom, itd. Osim ovakvih stvari slušamo još i o tome da su svoj politički utjecaj koristili za zapošljavanje poznanika i stranačkih kolega upitnih sposobnosti, da su putem njega stvarali uvjete za osobno bogaćenje (npr. mijenjanjem prostornih planova i drugih propisa), da su pronevjerili povjereni im novac ili uzimali provizije od onih kojima su dali da obave određene poslove za zajednicu za koju brinu, da su izravno štitili rođake i prijatelje kriminalnog ponašanja od sudskog progona, dolazili do seksualnih usluga političkim pritiskom, itd. Konačno, spočitavaju im se i poneki moralno problematični manevri kojima su riješili pitanja od neprijeporno javne važnosti. Skupa s tim se optužbama, gotovo bez izuzetka, zahtijeva povlačenje tih osoba iz kandidature za političku funkciju, njihova ostavka ili uklanjanje s dužnosti. Ti zahtjevi za opozivom takvih kandidata ili onih na funkciji najčešće su veoma uporni, protežu se kroz dulje vremenske periode ili opetovano pojavljuju čak i nakon više godina, te nerijetko rezultiraju uklanjanjem prokazane osobe s javne pozicije ili iz kandidature. Ovako nastupaju i misle, iskreno ili ne, ne samo spomenuti glavni „progonitelji” već i šira javnost, te brojni intelektualci, uključujući filozofe, koji nerijetko aktivno učestvuju u svemu tome - kao pokretači ili tek kasnije dodaju ovaj ili onaj detalj ovakvim prozivkama. Dosad spomenuto čista je faktografija, a u nju spada i stav većine onih koji pišu i govore o politici da je to nešto što tako treba i biti.

Međutim, takav mi se tretman političara u određenom, nemalom, broju spomenutih slučajeva čini potencijalno lošim, tj. kratkovidnim i veoma neproduktivnim, jer onemogućuje da na pozicije od javnog interesa dođu sposobni ljudi i da se tako postigne određeni boljitak za društvo. ${ }^{2}$ Odnosno,

2 Moja je pozicija tu paralelna onoj koju zauzima J. S. Mill u pogledu isključivanja žena iz „pristupa svim pozivima i poslovima”. On kaže (Mill 200o, 62-3): „Zar postoji toliki višak muškaraca sposobnih za najviše dužnosti da društvo mirno može odbaciti usluge bilo koje sposobne osobe? ... Odredba da neka vrsta osobe ne smije biti liječnik, ili odvjetnik ili član parlamenta nije samo na njezinu štetu nego i na štetu svih koji koriste liječnike, odvjetnike 
umjerenije rečeno, smatram da se netom opisana i ustaljena praksa barem ne bi smjela uzimati zdravo za gotovo. Mišljenja sam da ukoliko kandidat za političku funkciju ili onaj tko je već na njoj posjeduje sposobnost za uspješno obavljanje neke takve uloge, u mnogim mu slučajevima treba progledati kroz prste ako je nešto negdje i nekad moralno zgriješio. Ali prije negoli dodatno razradim ovu svoju poziciju, potrebno je provesti i osnovnu klasifikaciju moralnih posrtaja koje smo netom spomenuli. Neka tome posluže donja tablica i komentari uz nju.

\begin{tabular}{|l|l|}
\hline $\begin{array}{l}\text { Privatni se prekršaj čini u svojstvu } \\
\text { privatne osobe }\end{array}$ & $\begin{array}{l}\text { Privatni se prekršaj čini u svojstvu } \\
\text { javne osobe }\end{array}$ \\
\hline $\begin{array}{l}\text { Javni se prekršaj čini u svojstvu } \\
\text { privatne osobe }\end{array}$ & $\begin{array}{l}\text { Javni se prekršaj čini u svojstvu javne } \\
\text { osobe }\end{array}$ \\
\hline
\end{tabular}

Od navedenih se mogućnosti neću baviti jedino onom u donjem lijevom dijelu tablice jer bi to bili slučajevi u kojima se u svojstvu običnih građana čini nešto moralno problematično ne bi li se doprinijelo kakvoj javnoj stvari (primjer bi bila teroristička akcija), ali takvo se što malo kad dešava i iznimno je rijetko predmet prozivki o kojima govorimo. Gornji lijevi stupac također govori o privatnim osobama ali nam je relevantan jer osobe na političkim funkcijama ili kandidati za njih nepodopštine mogu činiti (i čine ih) u svom privatnom životu, odnosno one mogu biti nešto što nije vezano za njihovu aktualnu ili potencijalnu javnu ulogu, no političari se veoma često pozivaju na red zbog djela te vrste. Svi primjeri koji se u uvodnom odlomku spominju u prvoj grupi ilustriraju takve slučajeve. Nazovimo te prijestupe čisto privatnim. Desni se dio tablice odnosi na dvije različite vrste nemorala počinjenog na funkciji. Gornje polje govori o djelima koja su plod iskušenja u koja političari mogu upasti (prilika čini lopova) kada svoj položaj koriste za vlastiti probitak ili onaj njihovih najbližih i time upadaju u privatni nemoral na javnoj poziciji (ilustriraju ga primjeri druge grupe uvodnog odlomka). A donje desno polje predstavlja nemoral u koji mogu biti uvučeni kada se ponašaju isključivo kao političari, tj. dok djeluju samo kao predstavnici uloge koju žele uspješno odigrati. Te su posljednje radnje ono što je u političkoj teoriji poznato pod imenom prljave ruke. Rekoh da ću se pozabaviti svim trima zadnje spomenutim vrstama moralnih „grijeha” no najinteresantniji su mi prvi od njih, tj. oni koje nazivam čisto privatnim. Ti su, osobito u usporedbi s posljednje navedenim, slabo ili čak nikako teorijski obrađeni. Inspiraciju za razmišljanje o njima dobio sam promatrajući isključivo ono što se zbiva u političkom životu moje zemlje. Na akademsku se literaturu gotovo uopće 
nisam izravno oslanjao pa mi ona, dakle, nije niti pružila veću pomoć za taj aspekt ove cjelokupne teme jer ne poznajem baš nikakve tekstove o tom pitanju (što ne znači da ih nema) ${ }^{3}$. Niti mi je izvor bila inozemna politika, jer je ne pratim do takvih detalja.

Vratimo se opet mojoj tvrdnji da bi dobar dio onoga što se političarima predbacuje valjalo skinuti s liste relevantnih razloga za njihovo postavljanje na dužnost ili ostanak na njoj. Taj bi previd moralnih prijestupa trebao biti proporcionalan (ova 3 uvjeta predlažem kao prvu aproksimaciju pravila o tome): i) stanju u kojem se život društva u cjelini ili neko njegovo područje nalazi - ukoliko je on/o u većem rasulu i traži nove političke aktere koji će riješiti nastale probleme, manja bi se pažnja trebala pridavati moralnoj čistoći osobe; ${ }^{4}$ ukoliko, pak, društvo dobro funkcionira i nisu mu nužna poboljšanja, prihvatljivo je manje riskirati i ne dati ga na upravljanje osobi u čije se moralne kvalitete sumnja; ii) sposobnosti osobe za neku određenu funkciju: što je ona veća, mogu im se zanemariti veći moralni propusti.5 To ni u kojem slučaju ne znači da im počinjeni grijesi moraju biti oprošteni (u smislu osude i kazne) nego samo to da napuštanje ili odustajanje od javne funkcije ne treba biti cijena koju za njih moraju platiti, osim ako je to neizbježno zbog prirode sankcije koju ta osoba mora podnijeti (npr. ako na dovoljno dugo vrijeme mora u zatvor ili ako je temeljem prijestupa stekla neku titulu, nužnu za svoju funkciju, koju sada mora izgubiti i sl. $)^{6}$

3 Tek kada je ovaj tekst već bio u fazi recenziranja, obaviješten sam o radu koji u nekom smislu obrađuje ovo pitanje ali iz drugačije perspektive i služi se skroz različitim argumentima (Thompson 2004, 227-242). Njemu se tu pristupa iz aspekta toga čime bi se mediji u demokraciji trebali baviti a čime baš i ne bi, a zaključak mu je, vjerujem, u osnovi isti kao i moj: „Preokupacija privatnim porocima postala je javni porok. Rasprava o privatnim životima javnih dužnosnika zauzima nerazmjeran dio javne pozornosti i iskrivljuje karakter političke rasprave (ibid. 227)". Kažem da nam je zaključak isti, jer ako mediji ne trebaju obavještavati javnost, koja političare bira i kojoj su oni odgovorni, o raznim privatnim grijesima dužnosnika onda oni valjda i nisu relevantni za to hoće li ti pojedinci obnašati javne funkcije ili neće.

4 Uzmimo, primjerice, da je netko od aktera gorespomenutih prekršaja bio iznimno uspješan u povlačenju novaca iz međunarodnih fondova, u čemu se njegova zemlja dugo godina nije pokazala osobito efikasnom - dapače, više je u njih uplaćivala negoli dobivala. Zar bi takvog u ime potpune moralne principijelnosti trebalo odbaciti i opet se vratiti na staro, nezadovoljavajuće stanje?

5 Koliko se daleko s ovim previđanjem nemoralnosti može ići? Ide li to i do najvećih prijestupa, npr. ubojstava i sl.? Ne znam. Možda se ne može preći preko svega ali bi svakako preko mnogočega trebalo i možda je granica nejasna, ali tako je to u mnogim pitanjima. A moguće je i dodatno podešavanje tih obaju obzira jer neki moralno-karakterni nedostaci mogu biti nevažni za jedne a bitni za druge pozicije: npr. sadist kao ministar ekonomije ili kulture vjerojatno neće napraviti neku osobitu štetu ali kao ministar policije ili obrane to bi i te kako mogao. To vrijedi i za druge profesije: nervozna i nasilna osoba ne bi trebala raditi s ljudima iako je npr. sjajan vozač. Ona bi mogla voziti kamion ali ne i autobus, pogotovo ne školski.

6 Ovi uvjeti impliciraju odgovor na prigovor da su političari zamjenjivi i da nema neke veće štete u uklanjanju nekog tko se pokazao moralno iskvarenim. Moj je stav da „mašineriju” o 
iii) konačno, i najvažnije, ova se „amnestija” ne odnosi na bivše i/ili sadašnje moralne prijestupe koji idu na štetu uspješnom obavljanju političke uloge koju te osobe trebaju odigrati ili jasno upućuju na to da bi ono bilo slabo. No, možda bi ovaj ključni uvjet trebalo još dodatno oslabiti i/ili preformulirati, odnosno dopustiti političarima i neke propuste (barem kako ih se sada razumije) povezane s obavljanjem njihove funkcije, ukoliko neki iznimno važan posao obavljaju bolje od svih drugih ljudi za koje znamo.

Povežimo sada ove uvjete s gornjom klasifikacijom vrsta nemorala kod političara. Čini mi se očitim da oni nalažu znatno popustljiviji odnos prema čisto privatnom nemoralu negoli je to slučaj u ustaljenoj praksi i za standardno mnijenje. Jer ako društvena situacija traži učinkovito djelovanje, a stvari najčešće svugdje stoje baš tako, te ako je osoba za njega istinski sposobna, što je puno rjeđe, čemu je tek tako odbiti zbog nekog sumnjivog čina koji s tim djelovanjem nema jasne veze? Nadalje, izgleda da ovakvo postavljanje stvari potpuno zabranjuje privatni nemoral na javnoj poziciji temeljem trećeg uvjeta koji, opet, nikako ne isključuje svako nemoralno ponašanje posljednje vrste jer bi tako strog zahtjev implicirao da politička efikasnost nikada ne zahtijeva „prljave ruke”. Ako to ponekad ipak jest slučaj, onda se određeni nemoral, usko vezan uz njegovu dužnost, političaru mora dopustiti ali samo ukoliko je barem trebao i vjerojatno mogao voditi učinkovitom djelovanju koje njegova funkcija traži. Međutim, kako sam netom napomenuo, treći bi uvjet mogao biti unekoliko prestrog pa stoga vjerujem da njegova „mekša” verzija dopušta i poneki privatni nemoral na javnoj poziciji ili, alternativno, da bi opseg onoga što se takvim prijestupima smatra trebalo suziti i zatim na taj način pomiriti s početnom formulacijom tog uvjeta. Koja god od tih varijanti bila odabrana, mislim da ovo „omekšavanje” ipak ne treba ići onoliko daleko koliko tvrde oni koji smatraju da je ovaj uvjet prestrog prvenstveno zbog moje konzekvencijalističke argumentacije - jer bi se zabranom svakog „grijeha” štetnog za funkciju mogao eliminirati političar koji, ukupno gledano, napravi puno više koristi nego štete. Naime, izgleda mi da valjanost ove zadnje tvrdnje primarno ovisi od toga bi li kazne za privatne prijestupe na funkciji previše obeshrabrile talentirane pojedince da zauzmu potrebne funkcije ili to ne bi. Vjerujem da je ovo posljednje točno, pogotovo ukoliko se promjeni naše shvaćanje nagrada za uspješno javno djelovanje. O ovome malo detaljnije kad pokušam podastrijeti argument koji ide uz to. 
Uvodni dio predstavio je praksu/stajalište kojoj se opirem i ono što sam o tome mislim. Ali prije negoli pređem na argumente u prilog svom gledištu, nekoliko riječi o pretpostavkama na kojima gradim svoju poziciju. Naime, svakako bih želio izbjeći raspravu oko određivanja nekih temeljnih pojmova. Kao prvo, vjerujem da ne treba trošiti previše vremena oko definiranja toga što je ili tko političar: uzimam da je to bilo koja osoba koja obnaša neku (višu) funkciju u državnoj ili lokalnoj vlasti, te ima pravo odlučivanja o pitanjima koja se tiču svih građana pod njezinom ingerencijom i o raspolaganju javnim financijama. Tako ovdje u obzir uzimam prvenstveno predstavnike izvršne vlasti (i više rangirane diplomate), tj. one koji se politikom bave profesionalno a ne takve kojima je angažman u politici tek povremen (kao što su npr. poslanici u parlamentu). Ali moguće je da bi se rasprava mogla proširiti i na još neke druge funkcije, npr. sudačke. Drugo, puno je kompleksnije i prijepornije pitanje o tome što je moral na temelju kojeg se prosudba političara vrši. Odnosno, može se raspravljati o tome ima li on konzekvencijalističku ili deontološku formu, je li relativan ili apsolutan, objektivan ili subjektivan, itd. Ključno u svemu tome jest pitanje sudimo li svi o moralnim pitanjima isto ili ne. Jer ako svi o tome ne mislimo isto, pitanje o smislenosti moralne osude političara moglo bi biti bespredmetno jer naprosto ne bismo mogli odlučiti jesu li oni moralni ili nisu, budući da bi za neke od nas oni bili takvi a za druge ne bi, te ne bismo mogli donijeti niti nikakvu konačnu odluku o tome treba li im što prigovoriti. Pretpostavit ću, da bi rasprava imala smisla, da je moral nešto veoma strogo, sustav neprikosnovenih propisa i da ama baš svi dijelimo iste moralne stavove, tj. slažemo se oko (ključnih) moralnih pitanja - jer nam je to npr. urođeno evolucijom ili nešto slično tome. Istina, možda tako snažna pretpostavka o moralu i nije nužna budući da su svi obično spominjani grijesi političara takvi da se praktički sve moralne pozicije slažu oko toga da je takvo što nedopušteno. Drugim riječima, moglo bi se smatrati da u pogledu toga postoji stanoviti „preklapajući konsenzus” svih razumnih moralnih gledišta. Nadalje, ovdje moral uzimam prvenstveno u užem smislu, tj. kao tzv. politički moral koji se tiče prekršaja koji oštećuju druge osobe i čije se norme mogu provoditi i silom, ako je potrebno. I još ću, u vezi s time, pretpostaviti da su moralni grijesi koji se političarima stavljaju na dušu neprijeporno utvrđeni, te da ih treba javno iznositi bez ograda, kada budu otkriveni, da bi se jasno znalo kakvim smo točno ljudima povjerili zajedničko dobro. Što se pak upotrijebljenih primjera tiče, uzetih iz stvarnog života, koristim ih tek radi ilustracije i uzdržavam se bilo kakvog suda o njihovoj istinitosti, tj. o tome jesu li se dotične osobe (ovdje ipak neimenovane) uistinu tako ponijele ili nisu. Treće, da spomenem još neke svoje pretpostavke koje se odnose na narav politike. Uzimam kao dokazano da su nam političke funkcije uistinu potrebne (tj. da trebamo političare) i da 
politički život treba funkcionirati više-manje onako kako je to danas slučaj - odnosno, da trebamo podjelu na razne resore, upravljanje ovim ili onim sektorom života koje traži poznavatelje situacije u tim domenama - nasuprot npr. anarhistima bilo koje vrste koji bi odbacili stanje u kojem država uređuje i društvenu cjelinu i te sfere, te bi radije to prepustili privatnom ili civilnom sektoru. Još pretpostavljam da politika nije tehnika, odnosno nešto što se može algoritamski primijeniti u skladu s određenim pravilima i koju bi, shodno tome, mogao provoditi gotovo bilo tko - pa čak i računalo. ${ }^{7}$ Naravno, uzimam da je politički kontekst u kojem se sve ovo odvija u širem smislu demokratski, u smislu da javnost (tj. građani) ima utjecaj na to tko će obnašati političke uloge i da su joj njihovi nositelji odgovorni.

\section{3.}

Pozabavimo se konačno i samim problemom. Koji bi se izravni (ili pozitivni) argumenti mogli ponuditi za moj stav o njemu? Prvo, da krenemo s razine koja se odnosi na ljudsku narav, kako kaže David Hume (Hume 1975, 84), kada god čujete da za nekoga tvrde da je bio besprijekoran u svemu $^{8}$ znajte da to nije istina jer je ljudska priroda toliko slaba i nepostojana a iskušenja su toliko brojna da naprosto nema osobe koja bi uvijek mogla biti na visini normativnog zadatka, tj. življenja prema moralu. Ako ovo Humeovo opažanje uzmemo kao istinito i smatramo sumnjivim kada nam se podastire nešto suprotno tome, tj. da je netko u svemu i uvijek bio moralno dobar, kako onda možemo od političara zahtijevati da budu bića kakva zapravo ne mogu ni postojati? Ne moramo li tako i njima priznati ne samo mogućnost nego i biti uvjereni u (statističku) nužnost da posjeduju moralne slabosti? Ili da se vratimo još dalje u prošlost ljudskog iskustva, u smjeru ove Humeove primjedbe idu i znane kršćanske misli o tome tko će baciti prvi kamen, te o opreznosti u vezi sa strogim prosuđivanjem drugih, varijanta koja je navedena je kao moto ovog teksta. Odnosno, uzmimo još iz ove misaone tradicije i tvrdnju Aurelija Augustina o oholosti onih koji misle da su bez grijeha, pa time svojim temeljnim prijestupima dodaju još i ovaj (Augustin 1995, 259). ${ }^{9}$ Nadalje, kao zgodna literarna potpora za ovo isto mišljenje može poslužiti „test” kneza Miškina iz Idiota F. M. Dosto-

8 Misli li on ovdje na usko moralne kvalitete ili na neke koje spadaju u drugu vrstu ljudskih vrlina i slabosti, npr. lijenost i proždrljivost, ili pak na sve njih? Vjerojatno posljednje, budući da je to najviše u skladu s ostalim spomenutim argumentima (ili indicijama?) koje spominjem.

9 Od svih pred kojima sam branio ovu svoju tezu samo je jedan poznanik ustvrdio da se njemu nema što drugo zamjeriti osim toga da se ponekad, možda, ružno ošišao. Ali o njemu od drugih baš i nisam tako čuo. 
jevskog. Taj književni lik, naime, u jednom času predlaže da svatko od prisutnih javno ispriča najružniju stvar koju je u životu napravio i to baš ne nailazi na oduševljenje kod ovih. A ja ovdje pitam: koliko bi ljudi općenito bilo spremno biti iskreno kada bi ih se stavilo na takvu kušnju? Potpuno sam uvjeren da je ovo pitanje tek retoričko i da oko odgovora na njega nema velike dileme. Odnosno, da bi svatko tu imao ponešto za reći ali se to ne bi usudio. Iz toga se, uvjeren sam, vide dvije stvari: da svi moralno griješe i da ti grijesi nisu baš toliko neznatni kada ih treba skrivati. Ili ako se mogu pozvati na malo pučke mudrosti, odnosno na vic o dobrom čovjeku u raju koji se nakon par dana suhe i jednolične hrane požalio Sv. Petru da ga takva oskudna prehrana ipak iznenađuje s obzirom na mjesto na kojem se nalazi, koje bi po svemu trebalo biti savršeno. Odgovor koji je dobio jest da se naprosto ne isplati kuhati samo za njih dvojicu. Moglo bi se reći da ova šala ipak proturječi mojoj općoj tezi, posuđenoj od Humea, da nitko nije moralno savršen jer je barem taj jedan čovjek dospio u raj. Ali ako netko slučajno i jest uvijek bio moralno dobar, možda je naprosto imao tzv. moralnu sreću da bude takav, odnosno nisu se ukazale okolnosti koje bi ga navele na nemoralno ponašanje i na to da pokaže i svoje loše strane. ${ }^{10} \mathrm{Ili}$ uzmimo još možda, da se vratimo svakodnevnom iskustvu, činjenicu da se čini teškim čiste savjesti, tj. istinito, napisati posmrtni govor ako se držimo izreke da o pokojniku treba reći sve najljepše jer skoro nitko nije bio takav da mu se ne bi mogla pronaći poneka mana, a to je neprikladno uključiti u nekrolog. Zato će tvrdokorno istinoljubiv čovjek najradije izbjeći održati posmrtni govor ili napisati in memoriam. I bismo li zadržali ijednog prijatelja ako bismo o njima sudili moralistički ${ }^{11}$ strogo? Teško da bi to bio slučaj s obzirom na to koliko smo svi puni mana i koliko smo ponekad skloni slagati, ne održati obećanje, učiniti nešto na štetu bližnjeg, njime manipulirati, ugrabiti neku atraktivnu priliku prije njega, itd. Oni koji imaju tako visoke standarde vjerojatno će ostati usamljeni i depresivni, tješeći se pritom tek (krivom) idejom o tome da su jedino oni onakvi kakvi ljudi trebaju biti. Štoviše, često se može čuti da bi život s takvom osobom, kada bi je bilo, bio nesnosno naporan jer bi nam neprekidno prigovarala. U moralnom pogledu moramo bližnjima puno toga progledati kroz prste a i oni, naravno, nama.

Konačno, za političare na dužnosti ili za kandidate koji su već na njoj bili moglo bi se - ako su prije stupanja na nju i uspjeli nekako ostati

10 O ovome podrobnije videti Nagel, 1979. Okolnost koja bi te njegove loše strane mogla iznijeti na vidjelo mogla bi biti i dolazak na vlast.

11 Pod „moralizmom” ne mislim na svako pozivanje na moral pri procjeni našeg djelovanja nego na takvo koje moralna razmatranja automatski primjenjuje na sve i sva, te to čini s velikom dozom strogosti i beskompromisnosti. Prozivanje političara o kojem govorimo djeluje mi kao izrazit primjer tog diskursa. 
moralno ispravni - s razlogom pretpostaviti da za njih još više važi ovo što mislim da vrijedi za sve ljude. Naime, Toma Akvinski nije bez razloga tvrdio da dobar vladar, bez potrebe daljnjih propitivanja, zaslužuje vječno blaženstvo: ako ga moć koju je imao i velika iskušenja pred kojima se nalazio nisu naveli da moralno sagriješi, onda ga na taj put vjerojatno neće odvesti niti ništa drugo (Akvinski 1990, 87). S time je u skladu i stara uzrečica, a vole je koristiti i mnogi promatrači politike, koja kaže da ukoliko želiš vidjeti kakav je netko uistinu samo mu daj vlast. ${ }^{12}$ Međutim, ne znam je li Sv. Toma doista vjerovao da postoji ijedan istinski kandidat za ovaj izravan put u raj. Daljnji razlog koji nas odvodi i dalje u tom smjeru jest to što političari moraju djelovati u okružju koje prije resi loša negoli dobra moralna reputacija. ${ }^{13}$ A kako kaže Richard Dawkins, ako znate nešto o okolišu ili sredini u kojoj je netko dugo i uspješno djelovao, onda vam to daje za pravo da zaključite i nešto o svojstvima te jedinke - tj. da ona ima značajke koje joj omogućuju opstanak u takvoj sredini (Dawkins 1997, 12). A ako je ta sredina po pravilu znana kao moralno problematična, onda to ima jasne implikacije za moralnu kvalitetu osobe iole dugovječnog i uspješnog političara. ${ }^{14}$ Ukratko, sve nabrojeno zahtjev za moralnom čistoćom čini skoro nemogućim i neispunjivim i to u pogledu skoro svih triju vrsta moralnih zastranjivanja koje ovdje smatram relevantnim. Gornja razmatranja usmjerena na ljudsku prirodu ukazuju na to da teško možemo biti bezgrješni čak i u privatnim životima, dok opažanja Tome Akvinskog i Dawkinsa toj težini dodaju i „nadgradnju”, tj. ističu nova iskušenja koja neke od naših sugrađana još uvlače i u ono što smo nazvali privatnim grijesima na javnoj funkciji te do prljavih ruku. I ako je uistinu točno da se tipični političari pokazuju moralno lošijim od nas ostalih (u što sumnjam), rekao bih da to može biti jedino stoga što samo oni mogu upasti u prijestupe ovih dvaju zadnjih kategorija, koji neminovno pružaju prigode za zla većeg obima.

Naravno, može se prigovoriti da je sve dosad navedeno tek pseudoevidencija za moju tvrdnju o našim moralnim kvalitetama i da o tome

12 Slično misli i J. S. Mill, koji kaže (Mill 200o, 86): „Ako ovo govorenje [da su žene moralno bolje od muškaraca, nap. autora] služi bilo čemu dobrom osim možda kao muško priznanje da vlast ima štetan učinak: to je sigurno jedina istina u vezi s navedenom činjenicom... I doista je istina da je služenje, kada potpuno ne otupljuje, štetno i za roba i za robovlasnika ali manje za roba. Za moralnu je prirodu zdravije biti sputana samovoljom nego nametati svoju volju bez ikakvog ograničenja". Moram priznati da se ovo zapažanje može iskoristiti i protiv moje glavne teze, kako je dosad formulirana: ako ljudi dolaskom na vlast mogu postati opasni, onda treba dobro paziti koga ćemo na nju pustiti a čini se da su tu najsumnjiviji baš oni pojedinci koji su već ranije pokazali neke moralne slabosti. Na ovo pokušavam odgovoriti u prvom pasusu 5. odjeljka.

13 Vulgarna i veoma često citirana naša pučka mudrost kaže: „Politika je kurva”. Ne znam imaju li drugi jezici nešto poput te izreke.

14 To sigurno nitko nije snažnije izrekao od Machiavellija (1985, 125-26): ,... među tolikima koji nisu dobri mora propasti čovjek koji hoće da u svemu postupa kako je dobro". 
POLITIČKE PERSPEKTIVE

ČLANCI I STUDIJE

kakva ljudska priroda uistinu jest može prvenstveno odlučiti pažljivo empirijsko istraživanje. U načelu se teško ne složiti s ovom posljednjom konstatacijom ali ne i s prvim dijelom te kritike. Naime, praktički sve rečeno (a vjerojatno bi se moglo naći još mnogo toga u tom duhu) odražava naše bogato iskustvo o vlastitoj nam moralnoj naravi. Dapače, neki filozofi smatraju da je opća moralna nedostatnost ljudi i previše očita da bi je trebalo posebno dokazivati. Tako npr. John Kekes kaže: „Jasno je da zle radnje prevladavaju i da su odgovorne za mnoge ljudske patnje" (Kekes 1997, 27-8)'5; te „Svi će razumni ljudi priznati da zlo, u smislu koji je upravo razjašnjen [tj. kao rezultat ljudskih radnji] prevladava". (Kekes 1998, 72) ${ }^{16}$ Po njemu, jedino o čemu u tom kontekstu treba pričati jest zašto se to dešava, tj. zbog čega među ljudima prevladava nemoralno djelovanje.

Okrenimo se sad drugom bitnom razmatranju u ovom kontekstu. Naime, treba se upitati zašto postoji neka politička funkcija, što je njezin cilj? Nije li to uspješno obavljanje nekog više ili manje precizno određenog posla, npr. vođenja cijele zemlje, nekog užeg nacionalnog resora (kulture, obrane, znanosti) ili neke manje zajednice unutar nacije i nekih njenih resora, baš kao što je posao liječnika da nam uklanja zdravstvene tegobe, nastavnika da nam prenosi informacije i olakšava njihovo usvajanje a postolara da proizvodi solidnu obuću? Već je Platon smatrao da politika zahtijeva ekspertizu, da je ona posebna vrsta znanja koje ne može svatko imati budući da ono traži i poseban talent i dugotrajan trud da bi se do njega došlo. Naravno, pogriješio je u tome što u politici nije vidio ništa osim znanja, makar i najviše kategorije, jer se aktivnost političara prije svega sastoji u prosudbi između različitih vrijednosti, procjeni rizika i određivanju ciljeva. Znanje, naime, daje odgovore tek kad odredimo za kojim ćemo ciljem krenuti. Kako ističe Simon Blackburn:

15 Istina, Kekes ne smatra da baš svi ljudi imaju problema s moralom budući da dopušta postojanje tzv. moralnih svetaca. Ali naglašava (ibid. 33, kurziv moj): „Unutrašnji život ogromne većine ljudskih bića jest borba u kojoj sebičnost, okrutnost, pohlepa, zavist, mržnja i sl., na jednoj strani, te ljubav, pristojnost, sažaljenje, ljubaznost i sl., na drugoj, predstavljaju ratnike neupućenih vojski koje se sukobljavaju u tami. Takvi su ljudi izvor zla: pokvareni na određene načine i u određenim okolnostima a vrli u drugim, ljudi poput većine nas". Inače, jedan od stupova Kekesove kritike liberalizma jest da ukoliko uklonimo prepreke slobodnom ljudskom djelovanju i povećamo autonomiju pojedinaca, za što se (egalitaristički) liberali zalažu, rezultat će biti još više zla u svijetu a ne manje.

16 Opet valja priznati da Kekes, ne baš sukladno mojim idejama, tvrdi da uklanjanje zla u svijetu traži da i te kako pazimo na moralne kvalitete političara, nastavnika i drugih pojedinaca koji imaju utjecaj na stavove i ponašanje ostalih građana (ibid. 79-8o) ali naposljetku ipak zaključuje (ibid. 89-90): „Političke institucije dizajniraju i u djelo sprovode ljudi čija sklonost tomu da čine zlo vjerojatno nije niti jača niti slabija od iste te sklonosti kod ostalih ... Koja god uređenja ljudi stvorili, ona su osuđena odražavati njihova nagnuća i budući da je nagnuće činjenju zla jedno od njih sva će takva uređenja uvijek biti nesavršena”. 
Ali kod odluka koje političar mora donijeti ciljevi ne moraju biti i često nisu fiksirani. Problem jest $\mathrm{u}$ tome da ukoliko idete za jednim ishodom, tada je to i to način da ga postignete, ali ako idete za drugim onda trebate koristiti neki drugi način - no problem je odrediti za kojim ciljem ići. Ako želite dobit onda idite u rat; ako više vrednujete živote svojih građana onda nemojte ratovati. Vladar mora napraviti hijerarhiju mogućih ciljeva, ali tu mu nijedna struka ne može pomoći. U toj točci je razum [a znanje se zasniva na njemu, nap. autora] nijem. On može reći kojim putem ići ako je cilj taj i taj, te koji su tu rizici, ali ne može izabrati sam cilj ili reći koliko je važno izbjeći uključene rizike. (Blackburn 2006, 87-8)

Dakle, poslovi političara u temelju se svode na donošenje lakših ili težih odluka (npr. u što investirati proračunski novac i kojim točno sredstvima uopće doći do njega, da li ući u neki rat, sklopiti određeni savez, itd.), koje počivaju na faktorima koje spominje Blackburn, ali i na mnogočemu drugom kao npr. na balansiranju između različitih zainteresiranih i neusklađenih, pa čak i suprotstavljenih interesnih grupa, čime se u konačnici cijela šira ili uža zajednica usmjerava u ovom ili onom pravcu. A po riječima Jona Elstera:

Neki ljudi bolji su od većine nas pri integriranju ogromne količine difuznih informacija s različitim stupnjevima važnosti u jednu opću prosudbu. Oni posjeduju neuhvatljivu sposobnost suđenja. Uspješni generali, biznismeni i političari je imaju i baš zbog toga uspijevaju. Najbolje što mi ostali možemo postići jest da uočimo da tu sposobnost nemamo i da naučimo ne vjerovati svojim intuicijama. (Elster 2007, 128) 17 $^{17}$

Uz ovo spomenuto baratanje informacijama i sposobnost da se odvagne između svih ili većine vrijednosti do kojih držimo a koje su uključene u danu situaciju - tj. da se odredi kojima od njih dati prednost a koje žrtvovati i u kojoj mjeri (što se mijenja od prilike do prilike) - moramo još dodati i brojne druge poželjne osobine za obavljanje političkih funkcija. Među njih svakako spadaju čvrstina, odlučnost, inteligencija, brzina odlučivanja, dobra intuicija - brz i točan uvid u određenu činjenicu ili situaciju, u ono što doista leži pred nama (to ovisi o tome da se prema stvarima odnosi individualno a ne apstraktno i teorijski), sposobnost za dobru procjenu ljudi (i suradnika i protivnika), razne socijalne vještine - kao što su one potrebne za pridobivanje lojalnih suradnika ili umirivanje potencijalnih protivnika (Bobbio 1990, 152-3, o trgovanju s biračima i drugim strankama). Nadalje, tu su još i neke dodatne potrebne kvalitete političara koje se odnose na njihov temperament: oni ne smiju biti previše impulzivni i razdražljivi, previše nagli i lakomisleni, te slično tome (Mill 20oo, 68-71). Ukoliko imaju kakav manjak na tome planu, te recimo daju oštre njivi. 
POLITIČKE PERSPEKTIVE

ČLANCI I STUDIJE

i brzoplete izjave, lako mogu upasti u nepriliku s javnim mnijenjem ili sa svojim kolegama koji predstavljaju druge stranke ili države, a time u nevolje uvući i one koje predstavljaju. Bilo bi još dobrodošlo da barem političar na vodećoj funkciji bude, ako ne već narodski čovjek, onda barem netko tko ima dovoljno razumijevanja i senzibiliteta za ono što misli i osjeća prosječan građanin a ne da funkcionira kao neosjetljivi, hladni elitist ili intelektualac bez dodira s društvenom realnošću. I izražavanje bi mu trebalo biti svima razumljivo a ne pretjerano učeno. Tako bi vjerojatno imao i poštovanje i potporu najširih slojeva građana, te time lakše provodio razne mjere od kojih bi neke mogle biti i nepopularne - jer na neugodnu operaciju za kojom još ne vidimo potrebu lakše pristajemo ako vjerujemo liječniku koji nam je savjetuje.

Ukratko, ima jako puno toga što bi valjan političar morao moći izvesti i kakav bi trebao biti da može uspješno obavljati svoju funkciju. Zar je zadatak političara da, osim svega ovoga, bude i svetac ili moralni uzor (idol, heroj), kako bi to moglo izgledati na temelju zahtjeva za njihovu neporočnost? Nisam baš siguran da je tako. Nisu li ovi vanmoralni uvjeti već dovoljno (ili čak previše) zahtjevni te je teško naći nekog tko ih sve zadovoljava? ${ }^{18}$ Ako je tako, onda dodavanje beskompromisnih moralnih zahtjeva samo pogoršava stvari jer tako tražimo karakteristike koje (gotovo) nitko ne može imati. Međutim, ako nađemo čovjeka koji ima ove rijetke i izuzetne vanmoralne sposobnosti za političke funkcije, ili većinu njih, ima li se smisla odreći njegovih teško dosežnih usluga ukoliko nije i moralno čist ili čak besprijekoran? Zar bi nam bolji bio običan čovjek koji bi postupio po devizi „da mi je vlast samo na tri dana”, čak i da se radi o takvom koji bi zasigurno završio u raju, poput lika iz ranije navedenog vica? Bismo li radije htjeli da nas vodi netko te vrste? Teško da bi itko razuman na to pristao. U drugim se područjima života ljudi zasigurno ne odriču tako lako nekoga tko dobro, ili čak odlično, obavlja neki posao a ima neku veliku moralnu manu ili više njih (npr. kirurg koji je obiteljski nasilnik, ženskar, srebroljubac, podmitljiv ili nešto drugo; vrhunski nogometaš ili dokazano uspješan nogometni izbornik koji lažima štiti korumpirane menadžere teško da bi takvog pojedinca njihove ustanove ili klubovi otpustili). Radije ga nastoje držati pod kontrolom, te pokušavaju iznaći načine na koje će te mane što manje utjecati na obavljanje posla i neće oštećivati osobe oko njega. Uzmimo pokoji (grubi) povijesni primjer za to. Komunisti su, u svim zemljama gdje su dolazili na vlast, često uzimali u službu ljude koji su im bili ideološki strani, pa i mrski ili su čak ranije radili protiv njih, jer su uvidjeli da nemaju drugih, jednako dobrih stručnjaka za te poslove. Ili,

18 Malo je vjerojatno da je moguće da netko ima baš sve te odlike, no moguće je da nam u politici bar ponekad trebaju i ljudi sa skroz suprotnim karakteristikama, tj. da istodobno trebamo i golubove i jastrebove. 
usprkos vjeri u posvemašnju inferiornost Židova, nacisti su koristili njihove vješte ljude za sofisticirane poslove koje sami nikako nisu mogli tako dobro izvesti, npr. za tiskanje lažnog novca zapadnih saveznika, o kojemu govori film Krivotvoritelji. Zapravo, skoro je svaka vlast koristila vješte i iskusne osobe iz ranijih režima da za nju obave neke stvari. A postojali su tzv. ljudi „za sve režime” kao npr. knez Talleyrand (Harari 2015, 130). ${ }^{19}$ Jesu li svi ti vlastodršci griješili, ako stvar gledamo s pozicije političkog pragmatizma? Prije se čini da im je angažiranje takvih kadrova i te kako pomoglo da se održe na vlasti i ostvare ono što su naumili. Naravno, netko bi mogao reći da se u svim ovim primjerima radi o autoritarnim režimima, zasnovanim na problematičnim moralnim osnovama, no da liberalne demokracije moraju imati druge, strože kriterije. Međutim, čini mi se jako malo vjerojatnim da uspješnost obavljanja poslova - uključujući i onih političkih - ima puno veze s moralnim čistunstvom ljudi. Pogledajmo samo tko u demokracijama vodi npr. tajne službe.

Dva dosad navedena razmatranja trebala bi nas, vjerujem, navesti barem na ublažavanje našeg moraliziranja o bilo kojoj osobi koja se bavi politikom ili to tek nastoji. Prvim se htjelo pokazati da naprosto nijedan čovjek, ma koja mu god bila profesija i ma gdje bio, nije i teško može biti u potpunosti moralno besprijekoran. Stoga, kada bismo tvrdoglavo htjeli političara o kojem se baš ništa moralno problematično ne bi moglo otkriti vjerojatno nikada ne bismo imali niti jednog - baš kao što bi nas insistiranje na znanstvenoj teoriji koja nema nikakav nedostatak ostavilo bez ijedne od njih. ${ }^{20}$ Valja naglasiti da se ovaj argument može razumjeti i drukčije, naime kao da se htjelo reći da je licemjerno osuđivati drugog ako sam imaš neku mrlju i da to, stoga, tada nemaš ni pravo činiti. Ali kako god bilo s time, taj me aspekt ovdje ne zanima. ${ }^{21}$ Drugo razmatranje imalo je za cilj ukazati na to da političke funkcije nisu pozicije moralnih uzora i učitelja, od kojih bi se (valjda) ${ }^{22}$ moglo očekivati da žive u skladu sa svojim

19 Machiavelli, pak, vidi još jedan probitak koji vlastodršci mogu imati od ovoga (1985, 136): „Reći ću samo to da će vladar one ljude koji su mu u početku vladavine bili neprijatelji, a takvi su da im je potrebit oslonac da se održe, neobično lako privezati uza se: oni su toliko više prisiljeni da ga vjerno služe koliko vide da im je nužno da svojim djelima izbrišu loše mišljenje koje se o njima stvorilo. Tako vladar izvlači mnogo više koristi od njih nego od onih koji mu služe bez ikakve bojazni pa stoga zapuštaju njegove poslove".

20 Kako negdje kaže Imre Lakatos: „Sve su teorije rođene falsificirane”. Koliko znam, ovu tezu nitko nikada nije osporio. Naravno, ne mislim da je s ljudima baš doslovno isto kao i s teorijama, tj. da je istinita ona Augustinova (1982, 13): „Jer nitko nije čist od grijeha pred Tobom, čak ni dijete koje je proživjelo jedan dan na zemlji”.

21 Jedna od rijetkih ozbiljnih diskusija o tome može se naći u Cohen, 2006.

22 Veliko je pitanje jesu li i oni sposobni tako živjeti. Nije li opće poznato da su svi stoički mudraci priznavali da nisu uspjeli dosegnuti svoj ideal? A to definitivno nije uspjelo niti kasnijim moralistima s velikim zahtjevima npr. Peteru Singeru. Zgodan literarni prikaz te nemoći može se naći u romanu Iz prve ruke Joyce Caryija. Istina, tvrdnja koju ovdje doka- 
POLITIČKE PERSPEKTIVE

ČLANCI I STUDIJE

naucima. One su posvećene drugim zadacima i ne vjerujem da uopće traže da ih zauzimaju ljudi kojima se nema što moralno prigovoriti. Međutim, mislim da se moja pozicija može dodatno pojačati i proširiti dvama daljnjim razlozima koji se dotiču samo onih koji su već neko, duže ili kraće, vrijeme profesionalni političari ili su to već bili. Njima se, naime, ne traže samo nepodopštine koje su počinili van svoje funkcije nego i one koje su napravili u okviru nje (tj. grijesi s desne strane moje tablice). Ali sve što ću o tome napisati ima posljedice po ono što se može očekivati i od onih koji tek prvi puta stupaju na političke položaje.

4 .

Prvi od tih razloga upućuje na slijedeće. Ako mnogobrojni građani sve prije no rijetko izigravaju porezne propise, zlorabe uvjete propisane za primanje socijalne pomoći i za razne dobrohotne mjere poput subvencioniranja hrane i stanovanja, zaštite od ovih ili onih nedaća, te razne druge tipove državnih usluga, lažiraju bolovanja i slično tome, ${ }^{23}$ zbog čega ne smatramo razumnim inzistirati da su ti propisi, mjere i uvjeti sasvim ispravno postavljeni i da treba mijenjati ljude koji ih zloupotrebljavaju ${ }^{24}$ već, suprotno tome, te propise, mjere i uvjete težimo tako preformulirati

zujem jest da ljudi teško mogu izbjeći nemoral dok se u ovim primjerima često radilo o tome da ti moralisti nisu mogli živjeti po svojim strogim idealima, tj. po nečemu što predstavlja supereroganciju: primjerice da ne budu potreseni zbog neke nesreće ili da doniraju potrebitima cijeli dio svoje zarade koji im nije nužan za preživljavanje. Međutim, osobno vjerujem da su zakazali i u mnogo čemu drugome što ne doseže tu razinu.

23 Poznati primjeri ovih pojava su npr. novčana pomoć samohranim majkama, osiguranje od nezaposlenosti, nadoknada stočarima za životinje uginule od bolesti, poljoprivredni poticaji, određivanje maksimalnih cijena smještaja u doba raznih kriza, itd. Što se nevolja s davanjem novčane pomoći tiče, razrađen je model tzv. dileme socijalne pomoći po kojem ništa što se pritom napravi ne može ispasti dobro. Većina ovih pojava svodi se na ono što bi ekonomisti nazvali moralnim hazardom ili fenomenima u kojima treća strana plaća račun (Friedman 1992; Murray 1994). Valja usput primijetiti da ove pojave daju podršku tezi iz prve točke, tj. pokazuju moralnu slabost ljudi i koliko je rasprostranjena, te pogotovo osporavaju tezu onih koji misle da su političari čak i moralno gori od ostalih. Osim toga, zar se biračko tijelo rukovodi moralnim razlozima? Upravo suprotno: ono često podržava (očito moralno problematične) političare zbog svojih čak i veoma sitnih interesa, npr. malih dodataka plaćama i mirovinama. Današnji političari najčešće su populisti jer uočavaju da na vlast mogu najlakše doći (ili bez toga uopće ne mogu) ako podilaze zahtjevima masa koje si obično žele što lakše osigurati ono do čega im je stalo. Hayek je (1993, vol. 3, 52) neumorno isticao kako su brojne fiskalne mjere sračunate na to građani vjeruju da će za ono što oni žele platiti netko drugi, primjerice da će se sportski objekti u njihovom gradu izgraditi na trošak ostatka države. A opća slika politike nije ona gdje se biraju političke konstelacije koje su najmoralnije nego one koje najviše pridonose onome što većina misli da joj je u interesu, makar to bilo i na štetu drugih.

24 Ovo su, u vidu tzv. preodgoja, poduzimali neki revolucionarni ili vjerski režimi, ali to je prije završavalo katastrofom ili čak pokoljima građana negoli nekim uspjehom. 
(ili od njih potpuno odustajemo) da ne mogu biti lako zlouporabljeni? Zašto činimo tako, dok se u slučaju političara misli da uloge za koje se natječu moraju ostati fiksno definirane, t $\mathrm{j}$. da oni moraju igrati po pravilima koja ne treba mijenjati (dominantna vizija jest: političar mora nesebično raditi za javno dobro), i da umjesto iskvarenih treba dovesti druge, nove ljude koji te uloge i pravila neće zloupotrijebiti? Nije li tu razumnije postupati isto kao i u tim ranije navedenim slučajevima, tj. prilagođavati pravila igre za političare materijalu od kojeg nositelji tih pozicija moraju biti nužno napravljeni? Može li se, naime, razumno očekivati da političari budu moralno bolji od ostalih ljudi, da budu neka posebna ljudska vrsta koja neće gledati kako da izvrda svrhu pravila i da ih okrene na svoju korist? Moralist na politiku gleda isključivo kao na kadrovsko pitanje, tj. ne želi revidirati svoj jednostavni i rigidni sustav pravila i ukloniti njegove slabosti nego čeka „pravu” osobu kojoj će se povjeriti odgovorna funkcija i koja će zaboraviti svoj interes i raditi samo u javnu korist. Ali to ide protiv cijele tradicije realističke političke misli koja je na razne načine, npr. federalizmom, sustavima uzajamnih kontrola i ravnoteža, trodiobama vlasti i sličnim mjerama, nastojala i donekle uspijevala iznaći načine na koje se mogu spriječiti zloupotrebe političke vlasti. Bliže našem problemu, ne bi li bolje bilo npr. nekako plaćati gradonačelnike i druge političare ne fiksno već po uspješno obavljenu poslu, kao npr. konobare u Americi koji žive od napojnica koje neće dobiti ako nisu bili uslužni i pristojni prema gostima, pa bi tada i politička korupcija bila manja? Političari u Singapuru navodno su plaćeni prema svojem uspjehu u poticanju ekonomskog rasta, pa stvari s njima, kažu, stoje bolje otkad je uveden taj sustav (Harari 2017, 219). Milton Friedman na srodan način gleda lokalne vlasti, tj. one pojedinih saveznih država SAD-a, te smatra da je tu najbolje „glasovati nogama", tj. otići odatle ako vam ne odgovara kako se njima upravlja, čime tamošnji političari gube porezne prihode dok ih oni iz država u koje nezadovoljnici odlaze dobivaju, pa onda i ovi prvi moraju nešto promijeniti kako ne bi izgubili „klijente”. U istom su tonu sročene i ekonomske teorije demokracije Schumpetera i Downsa (Friedman 1992; Schumpeter 1981, 297-386; Downs 1957, 3-74). Svi ovi primjeri pretpostavljaju da političare treba čvrsto držati na oku i ne vjerovati im, tj. da valja misliti da oni neće baš biti moralni na javnom planu, ali da ih se može stisnuti i navesti da se bolje ponašaju kada se na njihove interese stavi prikladan pritisak ili doda kakva „mrkva”. Moralistička pozicija, pak, samim pozivanjem na potrebu da političare motri „unutrašnji policajac” pokazuje da je postojeća kontrola funkcionera, koja je u moći građana, manjkava. A slabo je vjerojatno da ta „unutrašnja uzda” može funkcionirati u doba kad su se religije u svom stvarnom utjecaju na ljudske umove znatno povukle i kad se njihovi svemogući bogovi, koji „ispituju srca i bubrege” te baš sve vide, čine 
prilično mrtvim, tj. takvima da ih malo tko uzima dovoljno ozbiljno. Neka političari otvoreno budu poduzetnici na planu svoje djelatnosti, u smislu da svi znaju da oni uglavnom rade za svoj a ne za javni interes, koji bi time bio tek usputna posljedica prvog, pa da dobijemo situaciju "privatni poroci, vrline javne". Štoviše, čak je i vjerojatno da nepostojanje takvog gledanja na njih i prikladnih mehanizama za prakticiranje te vizije stvara više političkog nemorala (naše druge vrste) negoli bi ga inače bilo. Drugačija bi pravila neizbježno sebično ponašanje dopustila i kanalizirala u podnošljivijem smjeru. Sada se npr. ne žalimo previše na tvrdnje nastavnika da slabo rade i nemotivirani su jer su im plaće male. No, oni ništa manje od političara „kradu”, u smislu da drže pozicije na kojima bi njihovi nezaposleni kolege možda bili bar malo radišniji i da trate vrijeme učenika. Primijenimo to i na političare: bar ponekad kada uzmu dio proračunskog novca za sebe, zapravo se ilegalno nagrade za napor i gnjavažu kroz koje su morali proći da za interes javnosti nešto obave. I tada ih prozivamo i progonimo. Ali da im je nagrada proporcionalna učinku morali bismo sankcionirati tek one koji su se „nagradili”, pa čak i samo primili redovnu plaću, a da nisu ništa značajno obavili. Ukratko, ovo razmatranje upućuje na to da nešto što po sadašnjim mjerilima predstavlja zloupotrebu političke funkcije u privatne svrhe po ovim revidiranim to više ne bi moralo biti takvo. Time bi sve moglo funkcionirati bolje i zdravije, a mogla bi se i sačuvati početna formulacija zadnjeg od moja tri uvjeta.

Posljednje i najbliže najpoznatijoj raspravi o moralu u politici, jer na ovoj točci kročimo na teren 'prljavih ruku', ne uzima li moralističko gledanje na politiku tu aktivnost prejednostavno, kao nešto što se mora vladati po relativno jednostavnim kanonima morala dok je, zapravo, svaki političar prisiljen činiti stalne kompromise, trgovati, oklijevati s odlukama i slično tome ukoliko želi polučiti uspjeh pri obavljanju svog posla - a to je najveći mogući prosperitet njegove zajednice u danom trenutku? Međutim, velik dio takvih ne-baš-moralnih djelovanja javnost percipira negativno i zbog toga ona političara često mogu koštati njegove pozicije, baš kao i u slučajevima koji su bili predmet razmatranja na prethodnim stranicama. Uzmimo npr. pitanje korištenja manjinskog pisma na natpisima javnih ustanova u gradu u kojem je ta manjina dosta brojna ali je većina krivi za neka ranije počinjena zla ili, pak, pitanje nacističkog pozdrava u naselju gdje je bio zloglasni koncentracioni logor ali koje su u nekom drugom razdoblju predano branili vojnici koji su se pozivali na takve parole i bez kojih bi, možda, ta obrana bila neuspješna. ${ }^{25}$ Nije li često bolje odustati od jednostrane odluke o takvim kontroverznim pitanjima koja će, u prilog koje god strane bila riješena, nužno ostaviti duboke podjele između građana (jer se

25 Vjerujem da bi za ilustraciju jednako dobro poslužio prijepor oko toga kako definirati obitelj, te brojne druge čarke između raznih ideološko-političkih opcija. 
tu tvrdoglavo razilaze) i radije lukavstvom ${ }^{26}$, trgovinom, odugovlačenjem ${ }^{27}$ ili skretanjem pažnje na druge, trenutno važnije teme ${ }^{28}$ izbjeći izravno odlučivanje o tome? Vjerujem da je nerijetko tako. Primijetimo ovdje i to da su neki političari dobri samo u nekim od tih manevarskih vještina i previše se oslanjaju na njih dok nam je zapravo potrebna osoba, ako takva uopće postoji, umješna ne samo u svim tim trikovima, ili barem u što više njih, već i sposobna procijeniti kada koji od njih primijeniti. Istina, sve ovo bi moglo zvučati kao da implicira relativizam o moralnim pitanjima, za koji sam u uvodu rekao da ću pretpostaviti da ne važi i da se svi slažemo oko moralnih stvari, no možda i ne nužno. Jer lako bi moglo biti da kompromise i trgovinu treba poduzimati čak i ako postoje moralno općeprihvaćeni odgovori na ovakve dvojbe koje političar mora razmrsiti, kao što npr. osobno smatram da su nacizam i sve što je uz njega vezano krajnje moralno loši, ukoliko bi opredjeljivanje za neki od suprotnih odgovora potenciralo podjele među građanstvom i možda vodilo teškim posljedicama koje se još daju izbjeći. A netko tko može napraviti takve kompromise i trgovine mora imati neke karakteristike koje ne bismo bez ostatka smatrali moralno pohvalnim, kao npr. mimikriju, lukavstvo i sposobnost manipuliranja drugima. Građanski mir (kao modus vivendi a ne kao preklapajući konsenzus) može u mnogim situacijama biti veća vrijednost od principijelnosti i promoviranja moralnih istina ukoliko je u tim trenucima prijetnja da ga se izgubi veća od prijetnje da će neka negativna ideologija pobijediti. Ludo je tražiti pravdu i istinu, makar i svijet propao. Ali ponekad, opet, treba i riskirati taj mir da bi se postiglo nešto važnije, obranila neka vrijednost od koje u tom trenutku ne smije biti odstupanja ${ }^{29}$ - pa dobar političar

26 Zgodan primjer političke lukavštine koja je brzo i glatko eliminirala problem jest manevar jednog političara s udrugom koja nije dopuštala da se s prometne ulice uklone prepreke koje je ona držala spomenikom. Političar je udrugu pohvalio i podržao, nasuprot brojnim kritičarima, te je njenim članovima za nagradu organizirao izlet, no te je prepreke uklonio dok su bili na njemu. Zbog sličnih vještina tog aktera i njegove navodne radinosti, jedan mi je prijatelj iz druge regije rekao da bi želio da dotičnog gospodina osude zbog njegovih nepodopština ali da mu kazna bude gradonačelničko mjesto u njegovu gradu.

27 Po jednom određenju, politika je umijeće odgađanja odluka sve dok te odluke ne postanu nevažne (tj. dok problemi ne ispare). I šteta je da, koliko je meni poznato, ne postoji neki novi Machiavelli koji bi razradio popis i detalje tih nužnih ali ne-baš-moralnih strategija za liberalno-demokratsko doba, u kojem su one (srećom) puno blaže no u stara vremena. Za poneku od njih videti Ricker 1986.

28 Poznati eksperiment socijalnih psihologa kod tzv. Razbojničke špilje predstavlja „klinički” uspješan slučaj ove strategije (Fischer 1990).

29 Ovakve prigode Leszek Kolakowski naziva (1964, 135): „Elementarne situacije; to su one situacije u kojima zamire taktika, tj. takve ljudske situacije prema kojima naš moralni odnos ostaje nepromijenjen bez obzira na okolnosti u kojima se te situacije ostvaruju... U elementarnim situacijama prestaje važnost nedosljednosti. Tu se odjednom sukobljavamo sa dvovalentnim svijetom". 
POLITIČKE PERSPEKTIVE

ČLANCI I STUDIJE

mora imati sposobnost ocijeniti kada treba poduzeti ovo ili ono od toga. Mislim da i dalje u politici trebamo lisicu i lava, ali radije većinom lisicu. A sad je već, vjerujem, više nego očito da su to i više nego zahtjevni uvjeti koji se izuzetno rijetko ispunjavaju u jednoj osobi. ${ }^{30}$

\section{5 .}

Ovo su bili izravni ili pozitivni argumenti za moju tezu. Treba im dodati i neke negativne argumente ili kritiku kritike, odnosno pobijanje argumenata onih koji tvrde da samo moralno besprijekorni ljudi trebaju postati političari, ako takvih argumenata ima. Malo ih se nudilo, barem u nekoj razvijenoj formi, a još je kudikamo teže o tome naći neku iole razvijenu i solidno branjenu teorijsku poziciju. Zato sam dosad kritizirao ustaljenu praksu i opće mnijenje jer za precizniju, brižno formuliranu tezu onih na suprotnoj strani niti ne znam. Uspješno bi pobijanje njihovih mogućih prigovora predstavljalo dobitak za moje stajalište jer bi se tako pokazalo da oponent nije uspješan. Na primjer, ono što se u tom kontekstu često čuje jest da privatni grijesi ukazuju na karakter političara koji bi se pokazao, te vjerojatno još i pogoršao, i na političkoj funkciji ili, pak, da to šalje lošu poruku ostalim građanima od kojih se traži da poštuju pravila i zakone. Prva od ovih tvrdnji, mislim, pada u vodu zbog mog trećeg uvjeta koji traži blokiranje barem većine pokušaja zloupotrebe položaja, što u demokratskim društvima nije neizvediv zadatak. Ali zaoštrimo još malo tu tezu mojih protivnika uz malu (i nadam se, prividnu) pomoć Arthura Schopenhauera. On je smatrao da su karakteri ljudi nepromjenjivi, da onaj tko je nešto učinio to će učiniti iznova i da baš svi mi ostajemo isti cijelog života (Schopenhauer 2005, 50-2). Ako je ta tvrdnja istinita, ona naizgled upućuje na to da treba maknuti političare koji su negdje i nekad nešto zgriješili. Ali to ne slijedi nužno, čak i ako prihvatimo takvu pretpostavku. Jer, kao prvo, ova rasprava ponajprije upućuje na njihove prekršaje u svojstvu privatne osobe a ne toliko na one u javnom ruhu - kojima kani malo smanjiti raspon ali ih i većinom želi oštro sprečavati. U tom bi se smislu njihova loša ćud iskazala većinom tamo gdje nam, kao zajednici, ne bi činila štetu. Kao drugo, čak i ako karakteri ljudi jesu stalni, te čak i ako se grijesi političara (a time i njihov karakter) ne mogu tek tako odvojiti od njihove funkcije, Schopenhaureova pozicija dopušta da se ostvari drugačija konstelacija

30 Ukoliko takve osobe nema, ne ukazuje li to samo još jednom na činjenicu da su vješti političari rijetki i nikako tek olako zamjenjivi? Spomenute vještine ukazuju na dodatne, rijetke sposobnosti koje trebaju krasiti uspješnog političara. Zar se lišiti čovjeka koji ih ima? Istina, vjerojatno se u realnosti trebamo osloniti na više pojedinaca koje odrađuju sve spomenuto ali ipak jedan od njih treba imati središnje mjesto i posjedovati neke ključne političarske „vrline”. Kako kaže Machiavelli $(1985,141)$ : „Vladar koji po sebi nije mudar ne može biti dobro savjetovan". 


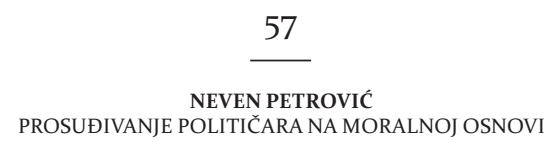

motiva i da se time postigne da isti karakter, u prikladno promijenjenim okolnostima (npr. u slučaju da smo dodali kazne i nagrade, te time promijenili poticaje), postupi drugačije nego kad te vanjske faktore nismo izmijenili. Druga od gornjih oponentskih teza pada zbog mog zahtjeva da svi plate za svoje povrede pravila. Primjerice, funkcionar koji je plagirao neko akademsko djelo ili kupio diplomu tako ne bi postao loš primjer za studente jer bi, ako se dokaže da je doista plagijator, odnosno da nije zaslugom stekao kvalifikaciju, izgubio akademske titule do kojih je došao temeljem tih prijevara. A oni bi mogli očekivati isti tretman, bez da se mogu pozivati na ikakav izuzetak, mada bi mogli doći na tu političku funkciju ukoliko bi imali njegove (pretpostavimo da ih ovaj doista ima) organizacijske sposobnosti. Međutim, u tom smislu i skroz ispravan dužnosnik bi trebao otići s pozicije ako je npr. omogućio da se zbog nekakvog animoziteta ukine uspješna akademska ustanova i umjesto nje formira nova $s$ viškom zaposlenih kadrova dvojbene kvalitete, jer time bi stanje u svom resoru promijenio s boljeg na gore. Toliko o ta dva često spominjana razloga za isključivanje iz političke igre onih koji su negdje nešto moralno zabrljali. Kao protuudar općem moralizmu u vezi s politikom mogla bi se ovdje još navesti i slijedeća opservacija. Nemoralna djela političara, kada se združe s čvrstim vjerovanjem i insistiranjem javnosti da ih oni nikako ne smiju počiniti, često dobro dođu onima koji su im nadređeni ili stoje negdje u sjeni da ove drže u poslušnosti, te da ih navode da postupaju onako kako te više pozicionirane i/ili manje vidljive osobe žele. Ako političari na to ne pristanu, njihovi „kontrolori” te informacije puštaju u javnost $\mathrm{i}$, kakav je već uvriježeni običaj, to dovodi do njihove smjene. Takav bi odnos, moguće, postao manje značajan i donosio bi manje štete ako funkcionare ne bismo tako lako smjenjivali zbog raznih privatnih nepodopština i ako bismo smanjili opseg ono što smatramo nedjelom na funkciji. ${ }^{31}$ Ukratko, ovo su načini pomoću kojih mi je dosad palo na pamet braniti svoju glavnu poziciju. Sigurno sam previdio i neke druge stvari koje bi mogle pomoći njenoj obrani, ali svakako i razne poteškoće koje opterećuju ono što sam dosad rekao. Ali evo malo i takvog materijala.

Prvo, činjenica jest da se optuženi političari od optužbi uvijek brane tvrdnjom da su neistinite, ukoliko to mogu. Znači li to da i oni sami priznaju toliku relevantnost moralnosti za obavljanje političkih uloga, baš kao i njihovi kolege koji ih optužuju, ili im je (objema) važno tek to što građani tako misle budući da im politički opstanak ili dolazak na položaj ovise o tome mišljenju? Moguće je i jedno i drugo, ${ }^{32}$ ali to ne dokazuje baš

31 Inspiraciju za ove misli dao mi je film Levijatan Andreja Zvjaganiceva.

32 Jedan se političar tako nije branio od optužbe da je jednom davno relativizirao zlo fašističkog koncentracionog logora zbog tadašnjih strateških razloga nego se odmah povukao s položaja počasnog člana udruge antifašista. 
POLITIČKE PERSPEKTIVE

ČLANCI I STUDIJE

ništa o vrijednosti takve procjene. Čak i da optuženi političari vjeruju u relevantnost morala za obnašanje funkcije, mogli bi biti u krivu. I nije jasno zašto bi veću težinu trebalo pridati onome što misle optuženi od onog što vjeruju tužitelji, kako to ovaj prigovor pretpostavlja. Drugo, možda političar ipak ima zadatak biti ne samo uspješan na svojoj funkciji nego i poslužiti kao moralni uzor za odgoj građana. Ljudi gledaju na političare i postaju im slični. Ako su ovi posljednji loši, ohrabrit će i druge da budu generalno takvi. Čak ih nerijetko obožavaju i možda za time imaju istinsku potrebu, pa su loši uzori na vlasti put ka općoj moralnoj iskvarenosti društva. Osim onog što sam već rekao, tj. da takvo što smatram neispunjivim uvjetom, na ovo mogu odgovoriti još i čvrstim osobnim uvjerenjem. Moj je pogled na politiku ciničan: uvijek je bila većinom nepoštena i takva će ostati, pa se s time valja pomiriti i iz toga izvući najviše što se može. Eventualno bismo mogli zagovarati dvoslojni moral, kao npr. kod Henry Sidgwicka ili R. M. Harea, pri čemu bi prvi sloj bio javan i propovijedao ono što se traži od neprosvijećenih, dok bi drugi bio kritički i rezerviran samo za upućene u srž stvari. Drugim riječima, u tome bi duhu trebalo javno propovijedati moralnost političara, ali bi više ili manje skriveno trebalo postupati po nečem sličnom mojim pravilima. ${ }^{33} \mathrm{~A}$ to je u skladu s onim što kaže Machiavelli, tj. da političari trebaju ponekad činiti i opake stvari ali da javnosti trebaju izgledati kao dobri, pa čak i da katkad odgovornost za prljavštine trebaju prebaciti na nekog drugog. ${ }^{34}$ Treće, netko bi se mogao zgražati nad nemoralnošću mog gledišta. To je prigovor koji najmanje pomaže racionalnom odgovoru na naš problem jer cijelo to pitanje moralizira i

33 Tako su nekako o Bogu mislili mnogi teoretičari: da ga nema trebalo bi ga izmisliti da bi se obuzdali sirovi i neuki.

34 Evo i njegovih riječi (1985, 130, kurziv moj): „Prema tome, vladar se mora dobro paziti da nikad ne izusti ništa što nije puno navedenih pet osobina; kad ga gledaš i slušaš, mora ti se činiti kao utjelovljeno milosrđe, vjernost, iskrenost, čovječnost, pobožnost. I nema ničega što bi vladaru bilo potrebnije nego da se čini da ima navedene osobine". Ali on kaže i nešto što izgleda suprotno ovome $(1985,126)$ : „Osim toga, ne mora se brinuti što će izići na zao glas zbog osobina bez kojih teško da bi spasio državu; jer razmotrimo li dobro, naći ćemo osobine koje će nam se učiniti kao vrline: povedemo li se za njima, eto gotove propasti; neke druge će nam se opet pričiniti kao poroci, a povedemo li se za njima, bit će nam na sigurnost i dobrobit". Slična se napetost može naći i u Machiavellijevom stavu o našem glavnom pitanju. Na jednom mjestu kaže $(1985,140)$ : „Kada vidiš da tvoj ministar više misli na sebe negoli na tebe i da svakom svojem činu gleda na svoju korist takav neće nikad biti dobar ministar i nikad se nećeš moći pouzdati u nj: tko upravlja nečijom državom ne smije misliti na sebe nego na vladara i ne smije vladaru ništa spominjati što nije u svezi s njim". Ali samo stranicu kasnije tvrdi $(1985,141)$ : „Svaki će od savjetnika misliti na sebe sama ... Drugačijih savjetnika i nema; jer ljudi će uvijek biti opaki, ako ih neka nužda ne prisili da budu dobri”. Ne znam kako je mislio pomiriti te izjave koje se čine nekonzistentnima. Što se posljednjeg poteza koji sam spomenuo tiče, Machiavelli kaže (1985, 132): „[V]ladari sve ono zbog čega mogu navući mržnju moraju prepustiti drugima”. Za osobito upečatljivu ilustraciju tog manevra videti Machiavelli 1985, 111 . 
pretpostavlja ono što treba dokazati, tj. tezu koju napadam. Ali u tom je kontekstu najbitnije ovo: sve što predlažem usmjereno je samo na to da se dobije maksimum za javnu stvar u situaciji u kojoj se nalazimo. Zar je takav cilj nemoralan? Kada bih svoju tezu zagovarao u ime ičijeg privatnog interesa prigovor bi vrijedio. Osnova moje pozicije jedino je to da se stoji što čvršće na zemlji, da se uzmu u obzir nužnosti svijeta.

Četvrto, možda zahtjev da se političari moraju ponašati striktno po moralu i zakonu, unatoč svim svojim nedostacima, ipak ima dubljeg smisla budući da su potencijalne zloupotrebe vlasti tih osoba veoma opasne i teško uklonjive, s obzirom na moć i poznanstva koja imaju na raspolaganju, pa je svaki oblik kontrole njihovog ponašanja dobrodošao. Drugim riječima, iako takav zahtjev površinski možda izgleda iracionalan on bi mogao biti utemeljen na mehanizmu koji ima istinski funkcionalnu osnovu kao što je slučaj s npr. ljubomorom prema sociobiološkoj teoriji. Možda to i jest tako ili donekle tako, ali bismo također moralne kvalitete političara trebali odvagnuti s koristima koje dobivamo ako za funkcionera uzmemo nekog nemoralnog. Dopuštam da moralnost može biti relevantan ali ne i apsolutno nužan uvjet za to da bi netko bio političar kojeg možemo prihvatiti, no uvriježena praksa ide na ovo posljednje. Peto, je li smisao moralne strogosti prema političarima možda taj da izbjegnemo tzv. sklisku strminu, tj. da se ne nađemo u nezgodi da ne znamo gdje da im točno počinjemo postavljati prigovore ukoliko započnemo s time da im ponešto i toleriramo? Čini mi se da na ovo dostatno odgovara moj treći uvjet koji traži da njihova nemoralnost ne smije biti na (veću) štetu uspješnog obavljanja njihove funkcije. Šesto, često se čuje pritužba da kada se čovjek koji je na političkoj funkciji ne smijeni unatoč nekom svom prijestupu time se pokazuje da svi građani nisu jednaki pred zakonom. Na to se dade odvratiti da se obične građane obično ne tjera da npr. zbog toga što su vozili automobil bez važeće vozačke dozvole ili su bili pripiti u prometu daju otkaz na poslu koji rade, niti se zahtjeva da ih se otpusti. A ne traži se niti da napuste funkcije koje imaju u nepolitičkim organizacijama, npr. sportskim ili drugim društvima. Ako se jednakost pred zakonom shvati tako kako misle oni koji insistiraju na ovoj primjedbi, onda bi ili svi ljudi u slučaju prekršaja trebali napuštati svoje poslove ili to ne bi morao nitko. Ili bi, pak, trebalo reći u čemu se sastoji ta golema razlika između političara i običnih građana. Što se mene tiče, jednakost pred zakonom jest samo u tome da i političari i nepolitičari trebaju podnijeti sankciju koja je za neki čisto privatni prekršaj određena zakonom, ali da dolazak na političku funkciju ili odlazak s nje s time nemaju nikakve nužne veze. Štoviše, ponekad političari tu lošije prolaze: npr. mnogi građani iz poreznih razloga prebivalište prijavljuju tamo gdje uistinu ne žive i malo tko obraća pažnju na to (jer tako se to radi), ali kada takvo što napravi funkcionar velike su šanse da će to mediji pronaći i da će se tražiti da bude kažnjen. 
POLITIČKE PERSPEKTIVE

ČLANCI I STUDIJE

Sedmo, može se smatrati da prigovori na ponašanje političara nisu samo moralni nego se veoma često odnose na to da oni ne poštuju zakone, pa ih čak i grubo krše. Time se postavlja pitanje: kako vjerovati ljudima koji se tako ponašaju a moraju ne samo paziti na poštivanje zakona nego ih predlagati ili čak donositi? Počet ću s napomenom da ovdje pretpostavljam da su zakoni u skladu s moralom, pa je svako njihovo kršenje istovremeno i kršenje morala dok obrnuto nije slučaj. Moral, ovako shvaćen, tako prema nama ima šire i jače zahtjeve - tj. on pokriva sve ono što traže zakoni a i mnogo više od toga. To se vidi i kad obratimo pažnju na činjenicu da su u stvarnosti zakoni često moralno upitni. Stoga bismo ponekad htjeli ljude koji su spremni kršiti takve neprihvatljive zakone, kao npr. nacističke rasne ili one na američkom Jugu, ili aktivno raditi protiv njih. Toliko o prvom, lakšem dijelu ove primjedbe. Međutim, zašto ponekad tolerirati one koji ne poštuju uvijek zakon a za njega su zaduženi? Nisam siguran da ovdje mogu pružiti potpun odgovor na to ali mogu skicirati u kojem bi smjeru mogao ići. Zakoni su nam potrebni ali samo stoga što smo ih svi kad-tad skloni prekršiti. Kada bi se svi ljudi, ili čak većina, uvijek ravnali po tome što oni traže, ne bi nam niti trebalo regulirati ponašanje kojeg se dotiču. Subjektivno gledano, potrebu za njima osjećamo primarno onda kada smo na udaru nezakonitog djelovanja ali ne kada smo mi ti koji od njega profitiraju. No, najčešće smo u ovoj prvoj ulozi i stoga većinom želimo poštivanje zakonskih normi. Ali da nas se u situaciji u kojoj nam povreda zakona koristi pita hoćemo li da on važi često to ne bismo htjeli. Na njega pristajemo tek kada stvari možemo sagledati mirno, s obzirom na ukupnu očekivanu korist jer zakon je norma koja većinu vremena koristi većini ljudi, ali svatko bi je ponekad mogao htjeti prekršiti. ${ }^{35}$ Iz ovoga bi, dakle, slijedilo da političarima, ukoliko su racionalni, u načelu možemo vjerovati kada zakone predlažu ili donose jer im je u interesu, kao i nama ostalima, da stvore pravila koja će većinu vremena koristiti svima, budući da su i oni i njihovi najbliži dio društvene cjeline. Ali ne možemo vjerovati, baš kao što to ne možemo nikome, da će oni sami te iste zakone uvijek poštovati. Opet, za druge će htjeti da to čine pa će tako paziti i na provedbu pravila. A sve to nije u neskladu s onim što ovdje zagovaram jer sam rekao da je korisno da se političare uvijek drži na oku i kažnjava za nepoštivanje zakona, ali na potpuno isti način kao i svakog drugog građanina. Međutim, mislim da je žalac ovog prigovora bio usmjeren na kvalitetu donesenih zakona i njihovu

35 O ovome podrobnije videti Hayek 1993, vol. 2. On na str. 4 kaže: „Majke koje se nikada ne bi složile oko toga čije bolesno dijete liječnik treba prvo pregledati lako će se unaprijed složiti da bi bilo u interesu svih da se on djeci posveti po nekom načelu koje povećava njegovu učinkovitost. Kada, pristajući na takvo pravilo, kažemo da je za sve nas bolje ako.., pod time ne mislimo da je sigurno da ćemo od toga svi na koncu imati koristi nego da nam to, na temelju znanja kojim raspolažemo, svima daje veće šanse, premda će nekima na kraju biti gore nego kada bi bilo prihvaćeno neko drugo pravilo". 
opću provedbu, a u tom mi pogledu ne izgleda da moje stajalište nailazi na poteškoću. U ovome bi smjeru, vjerujem, trebao ići i odgovor onima koji se pitaju u čemu bi to, po meni, političari trebali biti učinkoviti: pa u predlaganju i provedbi ovako shvaćenih normi, te donošenju raznovrsnih mjera korisnih za zajednicu. Toliko o prigovorima. Zasigurno ih ima još, pa čak i nekih suštinskih, ali bi čak i pokušaji odgovora na njih uzeli mnogo više prostora i vremena nego mi je trenutno na raspolaganju, pa neka radije ostanu za neku kasniju raspravu.

6.

Kao zaključak, da još odgovorim na to što je cilj ovog mog članka, što bih htio njime postići. Da li promjenu načina na koji građanstvo gleda na političare? Možda i to, ali prije svega bih htio utjecati na to kako ih intelektualci i većina onih koji formiraju javno mnijenje percipiraju te, naprosto, doći do istine o ovom problemu. Dio puta do ovog posljednjeg jest, naravno, intelektualna rasprava. Ali još mnogo više vjerujem u Hayekovo rješenje o tome kako procijeniti valjanosti bilo kojeg sustava društvenih pravila. Naime, probajmo svaki od njih iskušati u praksi pa vidjeti koji će nas najviše zadovoljiti, u smislu ispunjenosti naših preferencija. Dakle, konačan odgovor o ovom i drugim sličnim pitanjima može donijeti jedino usporedba društava koja su odlučila birati svoje vođe po ovdje kritiziranim, tvrdim moralističkim pravilima i onih koja su krenula postupati po nečem sličnom onom što ovdje predlažem. Vjerujem da bi ova posljednja strana prošla bolje. A naravno da bi i povjesničari ovdje mogli dati svoj značajan doprinos ukoliko bi se potrudili naći i usporediti političke sustave u kojima su primjenjivala oba ova sustava kriterija. ${ }^{36}$ I svakako valja naglasiti da je moja rasprava nepotpuna jer se prvenstveno bavi djelima političara ili političkih kandidata, tj. onime što su oni već učinili. Ali tu su i tzv. „verbalni delikti”, odnosno ono što su ti ljudi tek usmeno ili pismeno izrekli ili na neki drugi način iskazali (npr. odjećom) - čak možda ne i u potpunoj javnosti nego tek na društvenim mrežama ili čak u čisto privatnim porukama (pismima, elektronskoj pošti ili sms-ovima) koje su nekako procurile $\mathrm{u}$ javnost. Treba li ih i zbog toga progoniti i tražiti njihove ostavke ili ih micati iz kandidatura? Ovisi o čemu se točno radi - huškanju jedne grupe na drugu, „podgrijavanju” već napete atmosfere, nošenju fašističke odore

36 Ne znam je li moguće pronaći društvene sustave u kojima se u dovoljnoj mjeri postupalo na ova dva načina da to omogući usporedbu ali svakako se mogu naći brojni primjeri velikih državnika kojima bi se svašta moglo moralno zamjeriti. Schopenhauer je npr. smatrao da suvremene političare na skulpturama treba prikazivati u antičkim odijelima jer ih valja idealizirati budući da su veliki ljudi uglavnom puni mana pa bi njihovo otjelovljenje u odjeći koju su uistinu nosili te nedostatke sugeriralo (Schopenhauer 2013, 268). 
ili kape, ${ }^{37}$ izražavanju želje da pripadnici drugih rasa ne dođu u vašu zemlju ili pak antipatije prema homoseksualnim vezama - te u kojim je okolnostima došlo do toga. No ovo nije predmet mog rada. Ali i tu bi trebalo biti umjereniji no što je trenutno slučaj. Ovim se pitanjima npr. bavi Thomas Nagel $^{38}$, pa čak i kao uvjereni egalitaristički liberal smatra da se po tim pitanjima pretjeralo, te da je politička korektnost žestoko zastranila. ${ }^{39}$

\section{LITERATURA}

Akvinski, Toma. 1990. „O vladavini”. U Akvinski, T. Država. Zagreb: Globus: 47125 .

Augustin, Aurelije. 1982. Ispovijesti. Zagreb: Kršćanska sadašnjost.

Augustin, Aurelije. 1995. O državi božjoj II. Zagreb: Kršćanska sadašnjost.

Blackburn, Simon. 2006. Plato's Republic. New York: Atlantic Monthly Press.

Bobbio, Norberto. 1990. Budućnost demokratije. Beograd: Filip Višnjić.

Cohen, Gerald A. 2006. "Casting the First Stone: Who Can and Who Can't, Condemn the Terrorists?” In O'Hear, Anthony (ed.). Political Philosophy. Cambridge: Cambridge University Press: 113-36.

Dawkins, Richard. 1997. Sebični gen. Zagreb: Izvori.

Downs, Anthony. 1957. An Economic Theory of Democracy. New York: Harper and Row.

Elster, Jon. 2007. Explaining Social Behavior: More Nuts and Bolts for Social Sciences. Cambridge: Cambridge University Press.

Fisher, Ron. 1990. The Social Psychology of Intergroup and International Conflict Resolution. New York: Springer Verlag.

37 Ako je kandidat za političku funkciju nosio znakovlje neke nazadne političke struje u nekoj ranijoj dobi svog života, to je relevantno ili bi bar zahtijevalo da ga se provjeri jer ukazuje na njegova politička uvjerenja, odnosno upućuje na to da bi on možda provodio neke štetne politike ukoliko bi došao na funkciju. Ali moguće je da bi to trebalo tempirati prema poziciji na koju takva osoba pretendira jer na nekima od njih možda ne bi mogla učiniti nikakvog zla.

38 Nagel 1998, osobito 12-17, gdje on uvjerljivo pokazuje da funkcioniranje društva često ovisi o tome da se neke stvari ne spominju i ne iznose na površinu iako, moralno gledano, smetaju ovim ili onim ljudima.

39 Na mnogim korisnim primjedbama na ovaj rad iskreno zahvaljujem trojici anonimnih recenzenata za Političke perspektive, brojnim sudionicima nekolicine skupova na kojim sam izlagao njegove ranije verzije, Nevenu Sesardiću te, ponajviše, Viktoru Ivankoviću koji me ne samo iscrpno (usmeno i pismeno) kritizirao nego čak i snabdijevao literaturom, te uporno poticao da ovaj tekst napišem i, kasnije, da ga popravljam. Bojim se da sve te zahtjeve nisam zadovoljio, ali učinio sam najviše što sam mogao u vremenu koje mi je bilo na raspolaganju. 


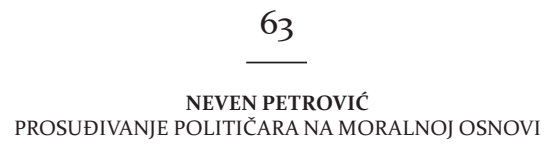

Friedman, Milton. 1992. Kapitalizam i sloboda. Zagreb: Globus/Školska knjiga.

Harari, Yuval N. 2015. Sapiens. Zagreb: Fokus.

Harari, Yuval N. 2017. Homo deus. Zagreb: Fokus.

Hayek, Friedrich A. 1993. Law, Legislation, and Liberty. London: Routledge.

Hume, David. 1975. Enquiry Concerning Human Understanding. Oxford: Clarendon Press.

Kekes, John. 1997. Against Liberalism. Ithaca \& London: Cornell University Press.

Kekes, John. 1998. The Case for Conservatism. Ithaca \& London: Cornell University Press.

Kolakowski, Leszek. 1964. „Pohvala nedoslednosti”. U Kolakowski, L. Filozofski eseji. Beograd: Nolit: 125-36.

Letwin, Shirley R. 1998. The Pursuit of Certainty. Indianapolis: Liberty Fund.

Machiavelli, Niccolo. 1985. „Vladar”. U Machiavelli, N. Izabrano djelo I. Zagreb: Globus: 99-147.

Mill, John S. 20oo. Podređenost žena. Zagreb: Jesenski i Turk/Hrvatsko sociološko društvo.

Murray, Charles. 1994. Losing Ground. New York: Basic Books.

Nagel, Thomas. 1979. “Moral Luck”. In Nagel, T. Mortal Questions. Cambridge: Cambridge University Press: 24-38.

Nagel, Thomas. 1998. “Concealment and Exposure”. Philosophy and Public Affairs, vol. 27, no. 1: 3-30.

Ricker, William H. 1986. The Art of Political Manipulation. New Haven: Yale University Press.

Schopenhauer, Arthur. 2005. Essay on the Freedom of the Will. Mineola: Dover Publications.

Schopenhauer, Arthur. 2013. Parerga i paralipomena. Beograd: Dereta.

Schumpeter, Joseph A. 1981. Kapitalizam, socijalizam i demokracija. Zagreb: Globus.

Thompson, Dennis F. 2004. Restoring Responsibility, Cambridge: Cambridge University Press. 
POLITIČKE PERSPEKTIVE

ČLANCI I STUDIJE

\section{SUMMARY \\ Judging Politicians Morally}

The author examines a prevalent practice to find politicians or candidates running for office morally deficient and to demand either their removal from office or disqalification from the political race. The author's main thesis is that such practice is, in many cases, irrational because it prevents qualified candidates from holding political offices. In order to defend this claim, these moral failures are first classified and then three main arguments are offered in order to show that in at least three types of cases politicians should not pay for their immorality with the political function they occupy or they aspire to occupy. Finally, some possible objections to the presented position are considered and answered.

KEYWORDS: purely private immorality, consequentialism, moralism, politicians, political realism, private immorality in public office, dirty hands. 